\title{
Prices and Quantities in the Monetary Policy Transmission Mechanism*
}

\author{
Tobias Adrian ${ }^{\mathrm{a}}$ and Hyun Song Shin ${ }^{\mathrm{b}}$ \\ ${ }^{a}$ Federal Reserve Bank of New York \\ ${ }^{\mathrm{b}}$ Princeton University
}

Central banks have a variety of tools for implementing monetary policy, but the tool that has received the most attention in the literature has been the overnight interest rate. The financial crisis that erupted in the summer of 2007 has refocused attention on other channels of monetary policy, notably the transmission of policy through the supply of credit and overall conditions in the capital markets. In 2008, the Federal Reserve put into place various lender-of-last-resort programs under section 13(3) of the Federal Reserve Act in order to cushion the strains on financial intermediaries' balance sheets and thereby target the unusually wide spreads in a variety of credit markets. While classic monetary policy targets a price (for example, the federal funds rate), the liquidity facilities affect balance-sheet quantities. The financial crisis forcefully demonstrated that the collapse of the financial sector's balance-sheet capacity can have powerful adverse effects on the real economy. We reexamine the distinctions between prices and quantities in monetary policy transmission.

JEL Codes: E44, E52, E58, G18, G28.

\section{Introduction}

Central banks have a variety of tools for implementing monetary policy, but the tool that has received most attention in the mainstream

*Adrian: Federal Reserve Bank of New York (e-mail: tobias.adrian@ny.frb. org). Shin: Princeton University (e-mail: hsshin@princeton.edu). The authors thank Douglas Gale and Lasse Pedersen for helpful comments. This paper was prepared for the inaugural International Journal of Central Banking (IJCB) conference "Provision and Pricing of Liquidity Insurance," held at the Federal Reserve Bank of New York on June 11, 2009. The views expressed in this paper are those of the authors and do not necessarily reflect the position of the Federal Reserve Bank of New York or the Federal Reserve System. 
literature has been the overnight interest rate. In the case of the United States, the Federal Reserve targets the "federal funds rate," an overnight interbank interest rate among U.S. banks with reserves at the Federal Reserve. However, mainstream models of monetary economics have virtually no direct role for the overnight interest rate to affect the economy. The conventional view is summarized forcefully by Alan Blinder (1998), who states:

Central banks generally control only the overnight interest rate, an interest rate that is relevant to virtually no economically interesting transactions. Monetary policy has important macroeconomic effects only to the extent that it moves financial market prices that really matter-like long-term interest rates, stock market values, and exchange rates.

Instead, the mainstream approach in monetary economics has been to emphasize the importance of managing market expectations. By charting a path for future short rates and communicating this path clearly to the market, the central bank can influence long rates and thereby influence mortgage rates, corporate lending rates, and other prices that affect consumption and investment. This "expectations channel" of monetary policy had become the dominant theme in many central banks, especially among those that practice inflation targeting. ${ }^{1}$

However, the financial crisis that erupted in the summer of 2007 has refocused attention on other channels of monetary policy, notably the channel that works through the supply of credit and overall capital market conditions. Borio and Zhou (2008) have coined the term "risk-taking channel" of monetary policy to describe the broad set of effects that work through expansive behavior of financial intermediaries and the feedback effects that result from the increased supply of credit.

One taxonomy that sheds light on the debate is to make a distinction along two dimensions:

(i) prices versus quantities

(ii) demand for credit versus the supply of credit

\footnotetext{
${ }^{1}$ The expectations channel is explained in more detail in Blinder (1998), Bernanke (2004), Svensson (2004), and Woodford (2005).
} 
The crisis management efforts since the eruption of the financial crisis illustrate well the first distinction between prices versus quantities. Central bank liquidity facilities that attempt to counter the shrinking of intermediary balance sheets have become a key plank of policy, especially after short-term interest rates were pushed close to their zero lower bound.

The Federal Reserve has put into place various lender-of-lastresort programs under section 13(3) of the Federal Reserve Act in order to cushion the strains on balance sheets and thereby target the unusually wide spreads in a variety of credit markets. Liquidity facilities have been aimed at the repo market (TSLF and PDCF), the commercial paper (CP) market (CPFF and AMLF), the foreign exchange (FX), and asset-backed securities (ABS) markets (TALF). In addition, the Federal Reserve made outright purchases of Treasury and agency securities, and liquidity backstops to money markets were increased via the Term Auction Facility (TAF) and foreign exchange Swap lines (FX Swaps). The common element in these liquidity facilities is to alleviate the strains associated with the shrinking balance sheets of intermediaries. The narrowing of spreads is a by-product of such actions. While classic monetary policy targets a price (e.g., the federal funds rate), the liquidity facilities affect balance-sheet quantities.

The balance-sheet expansion of the Federal Reserve as a result of the 13(3) liquidity facilities has refocused the monetary policy debate on the role of quantities in the monetary policy transmission mechanism. The financial crisis forcefully demonstrated that the collapse of balance-sheet capacity of the financial sector can have powerful adverse effects on the real economy.

It may be argued that the crisis management efforts of a central bank are driven by special considerations that are not operative under "normal" conditions. Against this, the counterargument is that the crisis did not erupt out of the blue, but instead culminated from a long accumulation of vulnerabilities that were left unchecked. The relevant question, then, is whether a focus on the risk-taking channel of monetary policy may have led to a better outcome.

In this respect, a reexamination of the conventional tenets of monetary policy is in order. The distinctions between prices and quantities and between the supply of credit and the demand for credit take on added weight. In order to understand the distinctions 
better, it is useful to review the effect of monetary policy on the demand for and supply of credit.

\section{Demand for Credit}

Credit is demanded by nonfinancial corporations, households, and the government sector (both central government and local government). Nonfinancial firms need to finance new investment in the physical capital stock, while households primarily finance the acquisition of housing and consumption. For consumption purposes, durable goods consumption such as auto purchases and consumer loans tends to be particularly important for the credit markets. The federal, state, and local government debt is also an important determinant of the demand for credit. Most of the public debt is financed via Treasury or municipal bond issuance.

For the corporate and household sector, the demand for credit is influenced by the level of interest rates, as well as credit spreads. In addition, households' and firms' net worth determines the extent of their borrowing capacity.

The standard visualization of the cost of demand for credit is the yield curve; it plots the yields at different maturities. In figure 1,

\section{Figure 1. The Term Structure of Interest Rates}

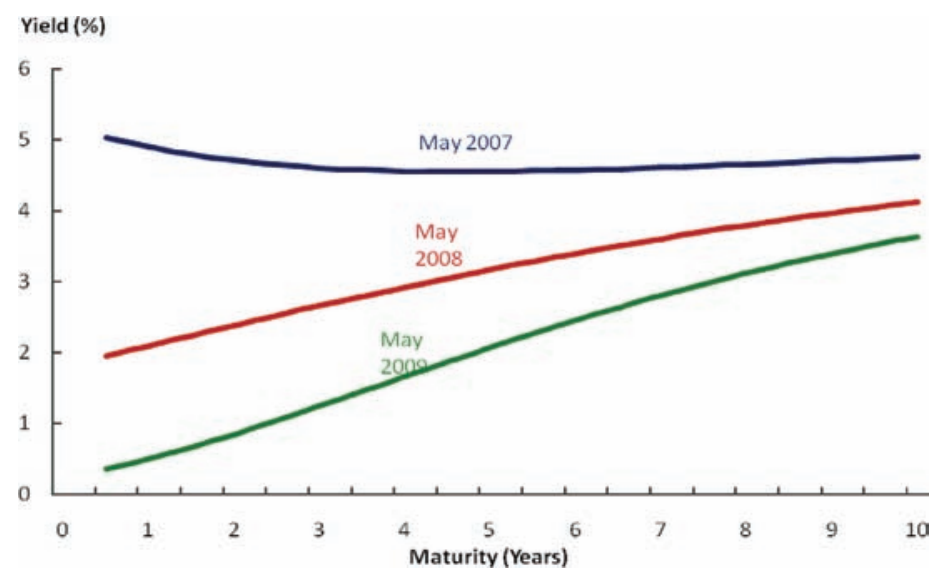

Source: Board of Governors of the Federal Reserve System. 
we plot yield curves for three dates: May 2007, May 2008, and May 2009. We can see that the yield curve was more or less flat in the spring of 2007, before the onset of the crisis. By May 2008, immediately following the Bear Stearns crisis, the federal funds target was cut from 5.25 percent to 2 percent, leading to a sharp steepening of the yield curve. By May 2009, the federal funds target was set to a $0-0.25$ percent corridor, giving rise to a further steepening of the curve. The federal funds target cuts were designed to lower the cost of borrowing, thus stimulating the demand for credit, and hence overall economic activity.

If the demand for credit is all that matters, then the position and slope of the yield curve (as well as the net worth of the borrower) are paramount. The expectations channel of monetary policy and the importance of the management of expectations are then well motivated.

\section{Supply of Credit}

Credit is supplied by financial intermediaries such as traditional commercial banks, as well as institutions of the "shadow banking system" such as security broker-dealers and ABS issuers. If credit supply is the main determinant of the quantity of credit in the economy, the key is to understand the motivation of financial intermediaries and how capital market conditions determine their behavior. For monetary policy, the question is how the central bank affects capital market conditions that ultimately affect the supply of credit.

The starting point in understanding credit supply is the delegation of capital allocation decisions to financial intermediaries. Savers - including households and nonfinancial corporationsdelegate capital allocation decisions to intermediaries. This delegation raises agency problems, which are (at least potentially) solved by constraints on leverage, risk management, and credit ratings, as well as targets for measures such as ROE or ROA targets. One particularly simple way to summarize such constraints is to look at haircuts - the amount of overcollateralization that is required for borrowing against risky asset collateral.

Monetary policy and lender-of-last-resort policies affect overall capital market conditions through the balance sheets of financial intermediaries. The variation of the federal funds target 
primarily moves around the slope of the yield curve, making the lendlong/borrow-short carry more or less profitable. Central bank liquidity facilities work through the equilibrium trade-off between credit spreads and haircuts. An increase of central bank lending against a particular asset class will tend to lower haircuts and spreads. As the financial crisis can be viewed as a shortage of financial intermediary balance-sheet capacity, lender-of-last-resort operations tend to offset the decline of that capacity. The Federal Reserve's balance-sheet expansion can thus be viewed as an emergency replacement of lost private-sector balance-sheet capacity by the public sector.

\section{Refocusing Monetary Policy}

Prior to 1980 , the monetary policy literature primarily focused on the role of monetary aggregates for the supply of credit. However, with the emergence of the market-based financial system, the ratio of high-powered money to total credit (the money multiplier) became highly unstable. As a consequence, monetary aggregates faded from both the policy debate and the monetary policy literature.

However, there is a sense in which the focus on balance-sheet quantities is appropriate. The mechanism that has amplified fluctuations in capital market conditions is the fluctuations in leverage and the associated changes in haircuts in collateralized credit markets. As the uncertainty of the future of mortgage-backed securities (MBS) increased in 2007, haircuts on MBS and ABS increased, forcing institutions to either unwind or move assets from off-balancesheet vehicles onto bank balance sheets. This shifted funding of long-term assets from collateralized asset-backed commercial paper (ABCP) and repo markets into the uncollateralized money markets, with the effect of massively increasing money market spreads, such as the LIBOR-Treasury spread.

Financial intermediaries tend to hold long-term assets, financed by short-term collateralized liabilities. In order to obtain funds, intermediaries lend out assets they already own and receive cash, which in turn can be invested in additional assets. The constraint on how much of such collateralized lending can be done is imposed by the level of haircuts. Haircuts can be thought of as the percentage downpayment an intermediary has to make in order to finance an asset. When a haircut is 20 percent, the intermediary can take out 


\section{Figure 2. The Haircut Curve}

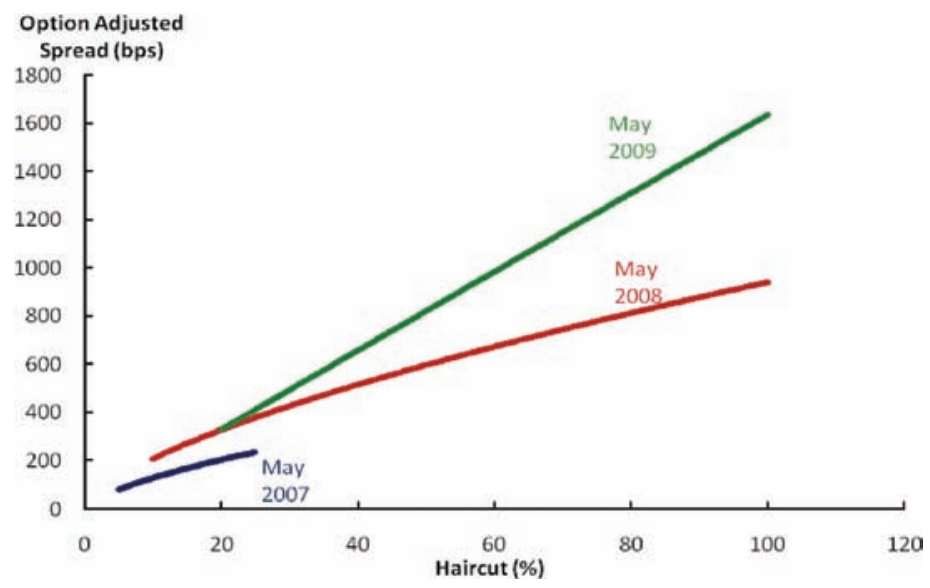

Note: Credit spreads are option adjusted. Haircuts are for DTC intraday borrowing. Source: DTC, Bloomberg.

a maximum leverage of $1 / 20 \%=5$. When haircuts increase from 20 percent to 50 percent, the intermediary has to unwind to $1 / 50 \%=2$ times leverage.

In this way, haircuts determine the amount of leverage that investors can obtain in repo markets. The haircut is the overcollateralization of a specific type of collateralized borrowing agreement such as the repurchase agreement (or repo) or other forms of collateralized borrowing such as agreements of the DTC.

One way to visualize the effect is through shifts in the haircut curve, plotted in figure 2. The curve plots option-adjusted credit spreads for corporate and ABS of different ratings against the percent haircut. The credit spread is a proxy for the expected return for being long the particular security and short the Treasury security of matching duration.

Recall that a 5 percent haircut means that an investor has to overcollateralize a particular repo transaction by 5 percent, thus allowing a leverage of $1 / 5 \%=20 / 1$. If haircuts for a particular security increase - say from 5 percent to 10 percent - the investor's maximum leverage is reduced from $20 / 1$ to $1 / 10 \%=10 / 1$.

The haircut curves of figure 2 represent equilibrium relationships between credit spreads and haircuts. Before the financial crisis, in May 2007, the maximum haircut for the most illiquid security of the 


\section{Table 1. Spreads and Haircuts for Fixed-Income Securities}

\begin{tabular}{|l|l|ccc|ccc|}
\hline & & \multicolumn{3}{|c|}{ Haircuts } & \multicolumn{3}{c|}{ Spreads } \\
\cline { 3 - 7 } & & May & May & May & May & May & May \\
& & $\mathbf{0 7}$ & $\mathbf{0 8}$ & $\mathbf{0 9}$ & $\mathbf{0 7}$ & $\mathbf{0 8}$ & $\mathbf{0 9}$ \\
\hline Corporate Debt & A & 5 & 10 & 20 & 86 & 235 & 364 \\
Corporate Debt & Baa & 5 & 20 & 30 & 115 & 278 & 508 \\
ABS & Aaa & 10 & 25 & 35 & 73 & 327 & 350 \\
Corporate Debt & Ba & 25 & 30 & 40 & 177 & 433 & 833 \\
Corporate Debt & B & 25 & 40 & 50 & 239 & 618 & 996 \\
Corporate Debt & Caa & 25 & 100 & 100 & 396 & 932 & 1,573 \\
\hline
\end{tabular}

Note: Credit spreads are option adjusted. Haircuts are for DTC intraday borrowing. Source: DTC, Bloomberg.

sample - Caa-rated corporate debt securities - was 25 percent (see table 1). In May 2008, this haircut had increased to 100 percent, implying that Caa corporate had become totally illiquid: these securities could no longer be used as collateral in repo transactions. At the same time, spreads of the Caa corporate had increased from 396 basis points to 932 basis points. Part of this increase in the spread likely reflected the deterioration of the underlying credit quality. However, part of the increase in spread simply reflected the inability of Caa securities to be used by levered financial institutions. For securities with a 100 percent haircut, the acquisition of the security has to be fully funded, as it has become impossible to borrow against the security. Caa corporate continued to have a 100 percent haircut in May 2009, while the credit spread increased to 1,573 basis points. Higher-rated securities, such as the Aaa-rated ABS that is used in figure 2 and in table 1, tell a similar story. Haircuts increased from 10 percent to 25 percent between May 2007 and May 2008, and then to 35 percent in May 2009. Over that time horizon, spreads increased from 73 to 327 , and then to 350 . Such a relationship between haircuts and credit spreads is a prediction of a general equilibrium asset pricing theory presented by Gârleanu and Pedersen (2009).

The haircut curve has three important dimensions: level, slope, and length. As the crisis unwound, the curve shifted up (i.e., credit spreads increased for any given haircut), the curve became steeper (i.e., each additional unit of haircut demanded a higher compensation in terms of credit spread), and the curve became longer, shifting 


\section{Figure 3. Repos and Financial CP as a Fraction of M2 (weekly)}

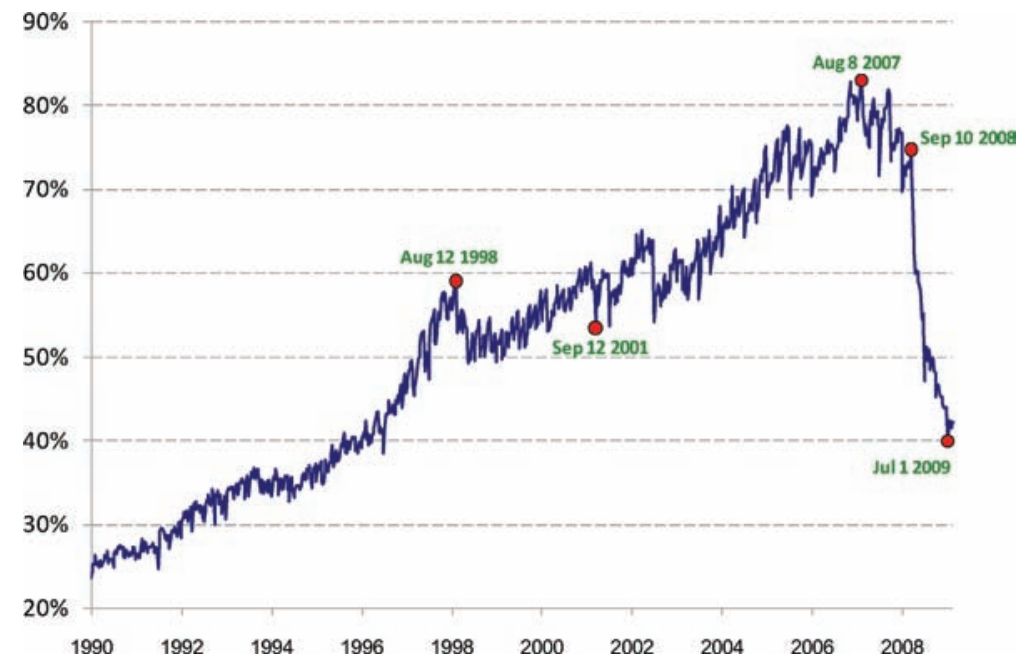

Source: Board of Governors of the Federal Reserve System and Federal Reserve Bank of New York.

to the right (the haircuts on the most liquid and least liquid securities both increased). Such shifts in level, slope, and length can be compared with the traditional level, slope, and curvature shifts of the Treasury yield curve (see figure 1). The major advantage of the plotting of the haircut curve is that it clearly shows the impact of the crisis: haircut increases are both causes and consequences of a financial crisis. In contrast, the term structure of interest rates does not unambiguously show a crisis. For example, the three yield curves of figure 1 happen to coincide with the financial crisis, but such shapes are not necessarily related to the crisis.

One consequence of the fluctuation in haircuts is the associated fluctuations in balance-sheet quantities. Figure 3 plots the sum of financial-sector commercial paper $(\mathrm{CP})$ and primary dealer repos as a fraction of M2. Financial CP is primarily used to finance the activities of the "market-based banking system" (sometimes called the "shadow banking system"). The market-based banking system comprises institutions that act like banks but that do not possess the "carrots and sticks" of banks. In particular, they are institutions 
that hold securitized credit on the asset side of their balance sheets (for example, pools of credit card receivables, pools of car loans, or pools of mortgages) and that finance those assets by issuing commercial paper. However, such institutions are not banks; i.e., they do not usually have access to the discount window or FDIC insurance (the "carrots") and are often subject to less regulation than traditional commercial banks (the "stick"). Such market-based banking institutions could be structured investment vehicles (SIVs), or finance companies. The other important set of market-based financial intermediaries are security broker-dealers. Broker-dealers often use repo transactions to finance their balance sheet.

Figure 3 shows that the short-term liabilities of the market-based banking system had reached a similar order of magnitude as the main short-term liabilities of the traditional banking system in August 2007 (money). The period of August 8, 2007-September 10, 2008 saw a slow decline in the share of market-based short-term liabilities relative to M2. This decline rapidly accelerated after the bankruptcy of Lehman Brothers in September 2008. By April 2009, the share of the market-based system liabilities had returned to a level below 50 percent, comparable to the mid-1990s.

\section{Central Bank Policy Rules}

Baseline macroeconomic models usually comprise three key state variables: the short-term interest rate (the federal funds target), real activity (GDP growth), and inflation (core CPI inflation). In addition, such models implicitly define a pricing kernel, allowing the calculation of the whole term structure of interest rates from the dynamics of the state variables. However, as we have argued above, such an approach is missing a key state variable: the leverage of the financial sector. Central bank policy rules can thus be expressed as functions of the three state variables:

$$
\begin{aligned}
\text { Federal funds target } & =F(\mathrm{GDP}, \text { inflation, leverage }) \\
\text { Quantitative policy } & =Q(\mathrm{GDP}, \text { inflation, leverage })
\end{aligned}
$$

The second rule superficially resembles monetary aggregate targeting. However, it is more directly related to broader aggregates, such as repos and commercial paper, which finance the shadow banking 
system. The liquidity facilities mentioned in the introduction (TALF, CPFF, etc.) can be directly viewed as such quantity policies.

Empirical asset pricing evidence strongly points toward the importance of the leverage factor in determining the cost of capital. Adrian and Shin (2007), Adrian, Etula, and Shin (2009), and Adrian, Moench, and Shin (2009) demonstrate for a wide variety of asset classes that leverage proxies can forecast excess returns, controlling for macro factors. These findings are significant, as they link balance-sheet quantities to asset prices, and hence provide the link that makes liquidity provision policies affect real economic activity. In addition, these results have the potential to solve long-standing asset pricing puzzles described in the macroeconomic literature.

\section{Monetary Policy Lessons}

Financial intermediaries lie at the heart of both monetary policy transmission and liquidity policies. The interaction of financial intermediaries' balance-sheet management with changes in asset prices and measured risks represents an important component in the transmission mechanism of monetary policy.

Financial intermediary balance-sheet management matters for the real economy, as well as for the soundness of the financial system. The lesson for the conduct of monetary policy is that the interaction of leverage constraints of financial intermediaries, short-term interest rates, and financial asset quantities are important to consider in conjunction. Our discussion suggests that tracking measures of financial market liquidity derived from the balance sheets of intermediaries has some information value in the conduct of monetary policy.

\section{References}

Adrian, T., E. Etula, and H. S. Shin. 2009. "Risk Appetite and Exchange Rates." Federal Reserve Bank of New York Staff Report No. 361. Available at http://newyorkfed.org/research/ staff_reports/sr361.html.

Adrian, T., E. Moench, and H. S. Shin. 2009. "Financial Intermediation, Asset Prices and Macroeconomic Dynamics." Working Paper, Federal Reserve Bank of New York. 
Adrian, T., and H. S. Shin. 2007. "Liquidity and Leverage." Forthcoming in Journal of Financial Intermediation.

Bernanke, B. 2004. "The Logic of Monetary Policy." Remarks before the National Economists Club, Washington, DC, December 2, 2004. Available at http://www.federalreserve.gov/boarddocs/ speeches/2004/20041202/default.htm.

Blinder, A. S. 1998. Central Banking in Theory and Practice. Cambridge, MA: MIT Press.

Borio, C., and H. Zhou. 2008. "Capital Regulation, Risk-Taking and Monetary Policy: A Missing Link in the Transmission Mechanism?" BIS Working Paper No. 268. Available at http:// www.bis.org/pub1/work268.htm.

Gârleanu, N., and L. H. Pedersen. 2009. "Margin-Based Asset Pricing and Deviations from the Law of One Price." Unpublished Working Paper, New York University and University of California, Berkeley.

Svensson, L. 2004. "Challenges for Monetary Policy." Comments presented at the meeting of the Bellagio Group of the G-10, National Bank of Belgium, Brussels, January 26-27. Available at http://www.princeton.edu/ svensson.

Woodford, M. 2005. "Central-Bank Communication and Policy Effectiveness." Paper presented at the Federal Reserve Bank of Kansas City's Symposium on The Greenspan Era: Lessons for the Future, Jackson Hole, Wyoming, August 25-27. Available at http://www.kc.frb.org/publicat/sympos/2005/sym05prg.htm. 